\title{
Conceptual model for assessing the effectiveness of inter-organizational relations in the tourism network
}

\author{
Natalia Rubtsova ${ }^{1, *}$, and Konstantin Solodukhin ${ }^{2}$ \\ ${ }^{1}$ Baikal State University, Lenin Str., 11, 664003 Irkutsk, Russia \\ ${ }^{2}$ Vladivostok State University of Economics and Service, Gogol Str., 41, 690014 Vladivostok, Russia
}

\begin{abstract}
Tourism industry as an object of management can be represented as a set of formal relations (interactions) between different organizations. Domestic and foreign researchers are unanimous in the opinion that the network interaction of companies is an important condition for the tourism industry effective functioning and for the sustainable development of a tourist destination as well. In terms of the named vector of scientific research, the efficiency of the inter-organizational relations (IOR) deserves special attention. At the initial stage of discussion are both the content of the IOR efficiency category and its assessment. The article presents a conceptual model for assessing the IOR efficiency in tourism in the context of a combination of three approaches: goal-oriented, functional and systemic. The authors identified the functions, goals, and indicators of the efficiency of inter-organizational relations in the tourism network.
\end{abstract}

\section{Introduction}

Inter-organizational relations and network interactions in various kinds and profiles of businesses have been studied by a number of foreign and domestic researchers [1-10]. In the last decade, the tourism industry has also been in the view of studying the issues of network interaction $[11,12,13]$. In the literature review on inter-organizational cooperation in the tourism industry presented by Pechlaner H., Volgger M. [13], the study of integration in tourism is stated to be currently presented rather fragmentarily. The authors give accent to a set of ideas which have gained certain development, such as: achievement of common goals, cooperation importance, successful tourism networks, communications, and joint innovations. The authors conclude that one of the relevant areas in the aspect of the network interaction theory, which has been attracting a growing academic interest in recent years, is network management in the tourism industry.

The tourism industry as an object of management can be understood as a set of formal relations (interactions) between various organizations, which include accommodation facilities (inns, hotels, hostels, etc.), tour operators and travel agencies, transport companies, sightseeing tour agencies, public organizations, migration and customs services, as well as

* Corresponding author: runatasha21@yandex.ru 
other entities directly and indirectly related to tourism. Inter-organizational relations (generally abbreviated as IOR in foreign sources) represented by such forms of interaction as association, alliance and cooperation [14] provide their participants with certain benefits: sharing resources, staff training, knowledge exchange, cost reduction in marketing and PR activities, and performance of management functions. In addition, effective IORs in the tourism network ensure the achievement of common strategic goals and quantitative and/or qualitative synergistic effects of certain territories where the tourism network operates [3]: local population employment, sustainable competitive advantage, development of the territory (tourist destination), and environmental problem solving.

According to the unanimous opinion of domestic and foreign researchers, the network interaction is one of the important conditions for the tourism network effective functioning. Its study in the managerial aspect is becoming an urgent research area. In terms of the named vector of scientific research, the assessment of the IOR efficiency deserves special attention. The subject of this article is the issue of assessing the IOR efficiency in the tourism network.

\section{Materials and Methods}

Yet many works have been devoted to the study of the IOR efficiency, the very concept of it still does not have a generally accepted definition. Indicating this notion, researchers use a whole range of related terms: "effectiveness", "efficiency", and "productivity". The terms are applied to inter-firm relations without preliminary discussion of when this usage is excusable. Currently, there are several points of view on the IOR efficiency interpretation. In particular, Russian authors [15] define it as "satisfaction of the interacting parties with the perceived values of the result indicators". Foreign researchers use the term "relationship quality" [16, 17, 18, 19]. In literature, similar definitions can be named differently: "strength," "success," "value," and "effectiveness" of relationships. The authors of this article adhere to the point of view of a goal-oriented approach to the IOR efficiency concept. According to this approach, the IOR efficiency is the degree to which the development goals of these relations characterizing the contribution to the creation of sustainable competitive advantages of interacting organizations are achieved.

To date, a significant number of models and methods have been proposed to assess the IOR efficiency. They use both separate indicators and multi-parameter scales and systems corresponding to a particular configuration or a concept of relationships. The most frequent measured characteristics are trust and satisfaction [17, p. 355], loyalty [18], intention to continue the relationships [19]. Summarizing the development results of domestic and foreign researchers, the IOR efficiency can be stated as a complex category with a significant number of various characteristics. That statement requires a systematic approach to the IOR efficiency assessment. A. Walter et al. [20,21] proposed the functional approach, which also deserves attention. The approach interprets the IOR efficiency through a number of direct and indirect functions reflecting various value aspects of relationships. In our opinion, the functional approach provides a wide range of possibilities for its use. For instance, it is possible to apply the model of relationship functions to detail the contribution of the relationships to the financial results of activities of companies belonging to the alliance; it is also possible to justify the goals of inter-organizational relations development.

\section{Results}

Summarizing the available developments on the issue studied and taking into account the ideas of the goal-oriented, functional and systemic approaches, the authors have formed a list of indicators for assessing the performance of certain functions and achieving the goals of 
the tourism network relations (Table 1). The presented functions of relations seem to allow deepening and clarifying the idea of "the efficiency of inter-organizational tourist network relations". The named idea is a "complex (integral) characteristic that determines the mutual purposefulness of parties involved to achieve tourist network development goals of relations and their contribution to the creation of sustainable competitive advantages".

Table 1. Relationship functions and examples of performance indicators of inter-organizational interaction in the tourist network

\begin{tabular}{|l|l|l|c|}
\hline \multicolumn{1}{|c|}{$\begin{array}{c}\text { Function } \\
\text { relations }\end{array}$} & \multicolumn{1}{|c|}{$\begin{array}{c}\text { Purpose } \\
\text { development } \\
\text { relations }\end{array}$} & \multicolumn{1}{|c|}{ Indicators } & $\begin{array}{c}\text { The nature of } \\
\text { the purpose } \\
\text { and indicator }\end{array}$ \\
\hline $\begin{array}{l}\text { Profit- } \\
\text { making }\end{array}$ & $\begin{array}{l}\text { Profit } \\
\text { maximization }\end{array}$ & $\begin{array}{l}\text { Net profit } \\
\text { Profitability (return on invested and tied } \\
\text { capital) }\end{array}$ & Monetary \\
\hline $\begin{array}{l}\text { Market } \\
\text { development }\end{array}$ & $\begin{array}{l}\text { Expanding } \\
\text { market share }\end{array}$ & $\begin{array}{l}\text { Marketing costs } \\
\text { The expansion of the customer base }\end{array}$ & Monetary \\
\hline $\begin{array}{l}\text { Personnel } \\
\text { development }\end{array}$ & $\begin{array}{l}\text { Reducing the } \\
\text { cost of personnel } \\
\text { management }\end{array}$ & $\begin{array}{l}\text { Search, training and personnel } \\
\text { adaptation costs }\end{array}$ & Monetary \\
\hline $\begin{array}{l}\text { Development } \\
\text { management }\end{array}$ & $\begin{array}{l}\text { Reduced } \\
\text { management } \\
\text { costs }\end{array}$ & $\begin{array}{l}\text { The cost of performing management } \\
\text { functions (access to information about } \\
\text { customers, competitors, new products, } \\
\text { new needs) }\end{array}$ & Monetary \\
\hline $\begin{array}{l}\text { Development } \\
\text { innovation }\end{array}$ & $\begin{array}{l}\text { Creation of } \\
\text { innovations }\end{array}$ & $\begin{array}{l}\text { Joint development of tourism products } \\
\text { Reduced development time and launch } \\
\text { of new tourism products }\end{array}$ & Non-monetary \\
\hline $\begin{array}{l}\text { Quality of } \\
\text { relations }\end{array}$ & $\begin{array}{l}\text { Increased } \\
\text { commitment and } \\
\text { trust in partners }\end{array}$ & $\begin{array}{l}\text { Reliability of partners } \\
\text { Stable relationship } \\
\text { Long-term relationship } \\
\text { Equality of partners } \\
\text { Fairness of relationship } \\
\text { Personalization (flexibility) of relations }\end{array}$ & Non-monetary \\
\hline
\end{tabular}

Note: developed by the authors

In the offered list (table 1), the indicators characterizing the IOR efficiency in the tourist network were selected in accordance with the logic of the implementation of the functions presented and the achievement of the corresponding development goals of relations. For instance, the implementation of the "profit" function logically corresponds with the "profit maximization" goal. The use of the "net profit" or "profitability" indicators in this case is appropriate and expedient. On the ground of the authors' definition of the tourist network IOR efficiency idea as well as on the ground of the described functions and development goals of relations, an appropriate conceptual model can be formed (fig.1). 


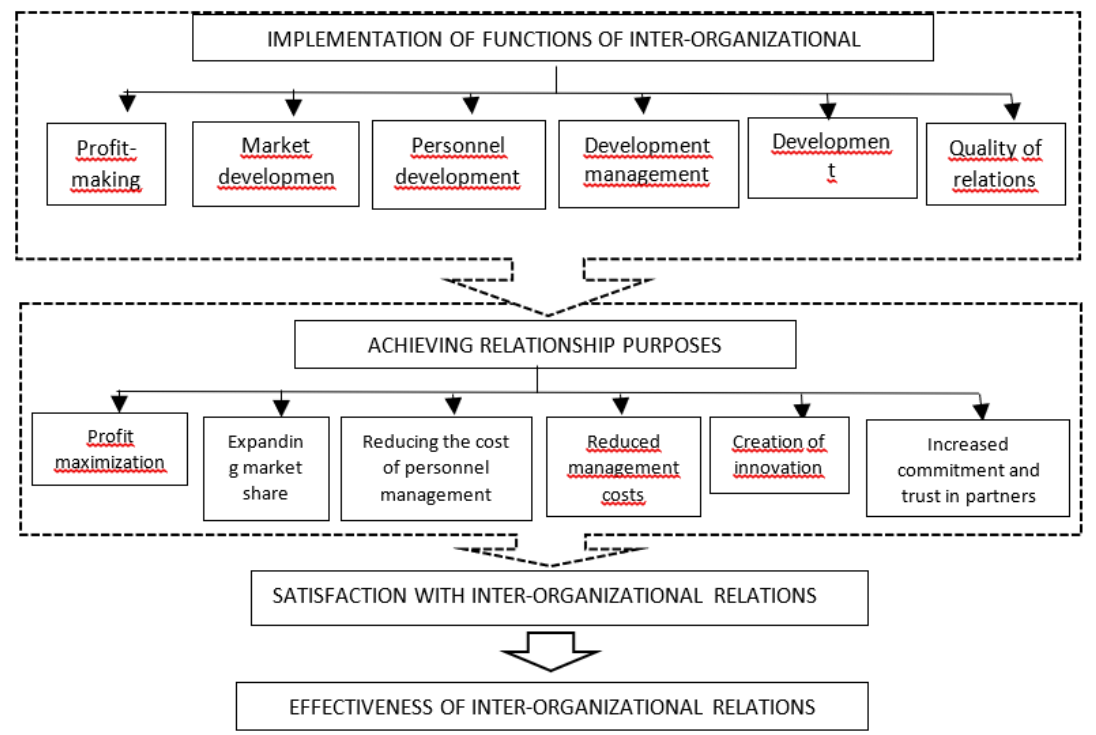

Fig. 1. Conceptual model for assessing the effectiveness of inter-organizational relations in the tourist network (developed by the authors)

In the given list of indicators (table 1), a group of non-monetary indicators that reflect the implementation of the "relationship quality" function deserves special justification. This term was first introduced in the research of marketing services [16]. Later, there were various examples of this idea operationalisation. The most common interpretation of the "relationship quality" contains a certain set of characteristics, such as alignment of interests, joint problem solving, trust, satisfaction, commitment, perceived value, etc. This paper authors hold to the view presented in $[19,22,23]$, according to which the quality of relations is a derivative of three key characteristics: trust, commitment, and satisfaction. In accordance with this approach, the authors define the goal of the relationship quality function implementing as increasing relationship satisfaction, trust, and commitment to tourism network partners. The authors believe that network members strive to develop relations with those entities cooperation with which causes greater satisfaction, trust, and commitment. However, the concepts of satisfaction, commitment and trust are many-sided and require additional specification. To demonstrate the creation of relation quality goals, the authors offer a set of six indicators: 1) stability, 2) continuity, 3) fairness and 4) personification (flexibility) of relations, 5) reliability and 6) equality of partners. Let us consider them in further detail.

We define reliability as a basic condition for trust formation between tourist network partners. Reliability is "the confidence of firm A in the reliability of firm B and the assurance of firm A that the actions of firm B will not intentionally lead to negative consequences for firm A" [24]. Ultimately, reliability forms trust among partners and is one of the key competitiveness factors of companies.

According to Morgan R., Hunt S. [25], relationship satisfaction leads to commitment in interaction with a specific partner. The commitment is defined as an effort to retain mutual relations or certain activities which are of high account for a company. It is characterized by continuity and stability (steadiness) in mutual relations and implies both the social involvement and the resource usage to maintain inter-firm relations. As a result of the increasing value created together with partners and strengthening personal ties, companies get economic and social advantages in the market. Therefore, continuity and stability can be affirmed to be fundamental derivatives of satisfaction with the relations of tourism network partners and with the resulting commitment. 
Fairness (profitability) of relations and equality of tourist network partners are also important conditions for achieving mutually beneficial cooperation, solving emerging problems and building a constructive dialogue between alliance members. Dependence on a partner leading to unfairness in relations can be viewed by a company as a fairly significant risk. Consequently, it can cause unwillingness to maintain and develop any relations. Thus, fair (mutually beneficial) and equal cooperation reinforce each other and lead to increased satisfaction with the relations.

In our opinion, personification of relations is a condition for the formation of commitment to a partner. It is predetermined by an increase in the level of heterogeneity and variety of forms of emerging relations between partners. The level depends on resources, strategy, and characteristics of companies. It is increased in the process of their adaptation to each other arising from long-lasting cooperation.

\section{Conclusions}

The paper presents a conceptual model for assessing the efficiency of inter-organizational relations in the tourism network. The authors have identified the functions, goals and indicators that characterize the IOR efficiency in the tourism network. The model presented demonstrates the interrelation between the efficiency and quality of inter-organizational relations. Special attention is paid to the characteristics of the relation quality components.

In addition, the issue of working out the integral indicator of the IOR efficiency (as well as the indicators included) deserves special attention when assessing the IOR efficiency in the tourism network with the help of the combination of goal-oriented, functional and systemic approaches. In particular, the BSC (balanced scorecard) and the SCOR (supply chain operations-reference model) model, which logic of the formation is widely used by researchers in supply chain management, can serve as the basis for the integral indicator formation. There is obvious academic interest in the development of various kinds of systems for assessing the IOR efficiency. As a result of this interest, varieties of proposals have appeared recently in this field. Notwithstanding, the issues under consideration are still insufficiently developed in the tourism industry. Therefore, this fact actualizes their further deepening and development.

\section{References}

1. K. Mason, P. Doyle, V. Wong, Ind Mark Manage, 35 (2006)

2. M. Emiliani, Sup. Chain Man., 8 (2003)

3. N. Rubtsova, Word Econ Manage, 4 (2018)

4. N. Rubtsova, Tomsk St Univ J Econ, 50 (2020)

5. N. Rubtsova, J Volg St Uni Econ, 22 (2020)

6. V. Samarukha, Com Telecom Contr, 3 (2012)

7. L. Sanina, Baik Res J, 3 (2014)

8. T. Svetnik, T. Bubaeva, Baik Res J, 5 (2011)

9. O. Chepinoga, M. Solodkov, A. Semenova, Baik Res J, 3 (2017)

10. O. Chistyakova, Bul Baik St Univ, 3 (2012)

11. M. Augustyn, T. Knowles, Tour. Manag. 21 (2004)

12. A. Morrison, P. Lynch, N. Johns, Int J Contemp Hosp Manage, 16 (2004)

13. H. Pechlaner, M. Volgger, Int J Cont Hosp Manage, 24 (2012) 
14. Y. Wang, D. Fesenmaier, Tour Manage, 28 (2007)

15. S. Kushch, A. Afanasiev, Russ J Manage, 1 (2004)

16. L. Crosby, K. Evans, D. Cowles, J Mark, 54 (1990)

17. P. Naude, F. Buttle, Ind Mark Manage, 29 (2000)

18. K. Roberts, R. Bea, Org Dynam, 29 (2001)

19. W. Ulaga, A. Eggert, Eur J Mark, 40 (2006)

20. A. Walter, T. Muller, G. Helfert, T. Ritter, Ind Mark Manage, 32 (2003)

21. A. Walter, T. Ritter, H. Gemiinden, Ind Mark Manage, 30 (2001)

22. K. Hewett, R. Money, S. Sharma, J Acad Mark Sc, 30 (2002)

23. J. Hibbard, N. Kumar, L. Stern, J Mark Res, 38 (2001)

24. U. Andersson, M. Johanson, L. Silver, Department of Business Administration: Uppsala (1996)

25. R. Morgan, S. Hunt, J Mark, 58 (1994) 